\title{
Consortium Application of Endophytic Bacteria and Fungi Improves Grain Yield and Physiological Attributes in Advanced Lines of Bread Wheat
}

\author{
Ghulam Muhae-Ud-Din ${ }^{1}$, Muhammad Amjad Ali ${ }^{1,2 *}$, Muhammad Naveed ${ }^{3}$, Khalid Naveed ${ }^{1}$, \\ Amjad Abbas ${ }^{1}$, Javed Anwar ${ }^{5}$, Muhammad Hammad Tanveer ${ }^{5}$
}

${ }^{1}$ Department of Plant Pathology, University of Agriculture Faisalabad, Pakistan

${ }^{2}$ Centre of Agricultural Biochemistry \& Biotechnology, University of Agriculture, Faisalabad, Pakistan

${ }^{3}$ Institute of Soil and Environmental Sciences, University of Agriculture Faisalabad, Pakistan

${ }^{4}$ Department of Agronomy, University of Agriculture Faisalabad, Pakistan

${ }^{5}$ Wheat Research Institute, AARI, Jhang Road, Faisalabad, Pakistan

\section{A R T I C LE IN F O}

\section{Research Article}

Received 13 July 2017

Accepted 12 January 2018

\section{Keywords:}

Consortium application

Endophytes

Grain yield

Moisture status

Wheat

*Corresponding Author:

E-mail: amjad.ali@uaf.edu.pk

\begin{abstract}
A B S T R A C T
Increasing human population places pressure on agriculture. To feed this population, two time increase in the current wheat production is needed. Today agriculture is becoming input intensive with more reliance on synthetic fertilizers and agrochemicals to fulfil the feed demand of the growing numbers. Use of synthetic fertilizer since last few years is impacting the soil quality. In this scenario, the use of beneficial endophytic microbes is an attractive strategy to overcome the use of synthetic products. To investigate the effect of consortium application of endophytic bacteria and fungus on plant growth, grain yield moisture status, a pot experiment was conducted in different wheat lines. It comprised four treatments like control, application of bacterial strain Bacillus sp. MN54, fungal strain Trichoderma sp. MN6, and their consortium (Bacillus sp. MN54 + Trichoderma sp. MN6). The effect of consortium application was more prominent and significantly different from the sole application of bacteria and fungus. The results showed that with a consortium application of endophytic bacteria and fungus, there was 28.6, 4.3, -6.3 and $3.7 \%$ increases in flag leaf area, chlorophyll content, relative membrane permeability and water content respectively. Consortia of endophytic microbes also resulted in the yield enhancement through the betterment of various yield attributes like number of spikelet's, grains per spike and grain yield per plant $(32.2,25.8$ and $30.8 \%$, respectively). So, consortia of endophytic microbes can greatly promote the progress of plants in dry land agriculture and increase the yield in an environmentally sustainable way.
\end{abstract}

DOI: https://doi.org/10.24925/turjaf.v6i2.136-144.1416

\section{Introduction}

Wheat (Triticum aestivum L.) is the major staple food crop in many countries of the world with special reference to Pakistan (Ali et al., 2010; Din et al., 2017). It is closely related with human nutrition, economic development and food security (Lawlor et al., 2013). More than one fifth of human population relies on wheat and its products for food. To meet the future food demand, two times increase in the current wheat production is needed (FAOSTAT, 2012). To achieve this goal, recent agriculture is becoming input intensive with more reliance on synthetic fertilizers and agrochemicals. Similarly, due to intensive use of synthetic fertilizers over the years has taken a toll on the health of soil as well as their quality (Verhulst et al., 2010). Increase in soil deterioration results in poor crop yields that is observed at several places. To maintain the health of soil it is the need of time to find out an alternative method which is effective, cheap and environment friendly (Pandey et al., 2013).

Use of plant growth promoting endophytes (PGPEs) is a technique which act as a bio fertilizer that improves host capacity for nutrient uptake, enhanced production, reduce the cost of fertilizer and eco-safe nature due to reduction in nitrogen leaching (DaSilveria et al., 2016). These are asymptomatic microbes found in almost all living plant species (Firáková et al., 2007). They form colonies in living tissue of plants without causing any deleterious effect on plants (Bacon et al., 2000). They can also help plants for fixing atmospheric nitrogen and production of siderophores which can solubilize and sequester iron and mobilize it for plant use. Similarly, they produce many growth stimulating hormones like Indole acetic acid (IAA), gibbrelic acid (GA) and abscisic acid (ABA) and 
cytokinin which plays a very vital role in the plant growth promotion and alleviation of biotic stresses (Mayak et al., 2004; Perring et al., 2007; Arendt et al., 2013). Many researchers also reported that PGPEs protected the plants from many deleterious abiotic stresses like salt (Mayak et al., 2004), over irrigation i.e. flooding (Grichko et al., 2001), and drought (Mayak et al., 2004). They also increase directly or indirectly water use efficiency, fresh and dry weight and different physiological responses of the plants i.e. increase in proline concentration which act as an osmoregulation agent (Han and Lee, 2005).

Bacillus sp. are endophytic bacteria which improve plant growth directly or indirectly by production of many phytohormones and antibiotics which kill other plant pathogenic bacteria (Bais et al., 2004). Plants induce systematic resistant against different types of pathogens by the process of mobilization and solubilization of phosphate (Idris et al., 2004; Erturk et al., 2010). In some studies, it is reported that Bacillus subtilis bacteria enhance the root and shoot length of plant, number of grains and size of the grains, fresh and dry weight, flag leaf area and chlorophyll contents of the treated plants (Waheed et al., 2014; Aboud et al., 2014; Barutcular et al., 2015). Similarly, Trichoderma sp. is a plant growth promoting fungus which belongs to Ascomycetes. It is used as a biofertilizer, biocontrol agent and promotes the growth of the plants against various biotic and abiotic stresses (Mastouri et al., 2010; Murali et al., 2012). It also play an important role in nutrient absorption by colonizing the roots and enhance the chlorophyll content, fresh and dry weight of the plant leaf, increase flag leaf area, grain yield and plant height (Azarmi et al., 2011).

The potential of Bacillus subtilus has been exploited to control plant diseases under control and natural field conditions (Joseph et al., 2007). However, little information is available on the combined use of Bacillus sp. and Trichoderma sp. for improving plant growth and disease suppression in wheat (Mastouri et al., 2010; Murali et al., 2012; Adams et al., 2007; Harman et al., 2004; Yedidia et al., 2001). So, the present study was designed to evaluate the synergistic use of Bacillus sp. MN54 and Trichoderma sp. MN6 for enhancing growth and yield attributes and traits expressing the moisture status in different wheat lines and disease suppression in wheat.

\section{Materials and Methods}

Culture Preparation of Bacillus sp. MN54 and Trichoderma sp. MN6

The Bacillus sp. MN54 was previously evaluated for enhancing growth and physiological attributes of Quinoa under normal and salt-stressed conditions (Yang et al. 2016). The inoculum of selected bacterial strain MN54 was prepared using 10\% Tryptic Soy Broth in $1000 \mathrm{~mL}$ Erlenmeyer flask incubated in a shaking incubator

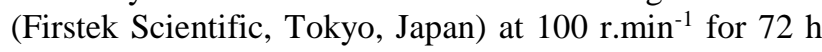
at $28 \pm 1^{\circ} \mathrm{C}$. An optical density of the inoculum was adjusted to 0.5 measured at $\lambda 600 \mathrm{~nm}$ using spectrophotometer to obtain a uniform population of bacteria $\left(10^{8}-10^{9}\right.$ colony forming unit $\left.(\mathrm{CFU}) \mathrm{mL}^{-1}\right)$ in the broth at the time of inoculation.
The fungus inoculum was produced by potato dextrose broth in $1000 \mathrm{~mL}$ Erlenmeyer flask incubated in a shaking incubator (Firstek Scientific, Tokyo, Japan) at 100 r.min ${ }^{-1}$ for 5 days at $28 \pm 1^{\circ} \mathrm{C}$. The spores of the Trichoderma sp. were analyzed by using Hemocytometer to obtain a uniform population of fungus $\left(10^{6}-10^{7}\right)$ spores $\left.\mathrm{mL}^{-1}\right)$ in the media at the time of inoculation. The selected microorganisms Bacillus sp. MN54 and Trichoderma sp. MN6 were very kindly provided by Soil \& Environmental Microbiology Laboratory, Institute of Soil and Environmental Sciences, University of Agriculture Faisalabad, Pakistan.

\section{Plant Cultivation and Strain Inoculation}

Twenty wheat (Triticum aestivum) lines 126, 121, $135,128,144,123,107,127,130,120,101,118$, $137,110,124,104,140,113,142$ and 106 were taken from Wheat Research Institute, Ayub Agriculture Research Institute (AARI), Faisalabad, Pakistan and were grown in pots with non-sterilized soil at the Department of Plant Pathology, University of Agriculture Faisalabad, Punjab, Pakistan during the year of 2015-2016. Ten seeds of each line were sown in each pot. Each line was repeated three times. Pots were irrigated after every 3 days. After germination, thinning was done and maintained three plants in each pot. Bacterial and fungal inoculation was performed by adding $6 \mathrm{~mL}$ of each bacterial and fungal culture on each pot with the help of pipette near the root zone of each plant. In the consortium interaction $3 \mathrm{~mL}$ bacteria and $3 \mathrm{~mL}$ fungus were applied near the root zone of each plant.

Determination of Morph-Physiological Characteristics

Flag leaf was cut at the base at anthesis stage early in the morning (at 8-9 am) when leaves were in turgid position and were placed on the plane page. Flag leaf area (FLA) was measured by the following formula; FLA= (length $\times$ width) $\times b$, where ' $b$ ' is a constant $(b=0.75)$ (Ahmad et al., 2015). The width was measured from three different places of the blade. After that, these leaves were oven dried at $74^{\circ} \mathrm{C}$ in the oven for 48 hours and determine its dry weight (DW) in grams (g) by using an electronic balance.

Flag leaves were used to measure relative membrane permeability and chlorophyll contents. The leaves were cut with scissors, pack into the zip bag and transferred to the laboratory. For the relative membrane permeability leaves were cut into small equal pieces and transfer into the test tube containing $20 \mathrm{~mL}$ of deionized distilled water. The test tubes were shaken with the stirrer for $10 \mathrm{~s}$ and this solution was assessed for initial electrical conductivity (EC0). For the (EC1) these test tubes were kept at $4^{\circ} \mathrm{C}$ for 24 hours and then assayed. Then these samples were autoclaved at $121^{\circ} \mathrm{C}$ for 25 minutes for the determination of (EC2). Percent relative membrane permeability can be determined by the following formula given by (Yang et al., 1996).

\section{$\operatorname{RMP}(\%)=\mathrm{EC} 1-\mathrm{EC} 0 / \mathrm{EC} 2-\mathrm{EC} 0 \times 100$}

To measure the chlorophyll contents, the chlorophyll meter was used (SPAD 502 plus, Minolta, Japan). Chlorophyll contents of flag leaves of each genotype in each treatment were measured at least from four different areas on the same leaf. 
Flag leaves were used to determine the relative water content. Immediately after excision the leaf fresh weight (FW) was measured. After that, leaves were placed in the test tube containing distilled water for 24 hours at $4^{\circ} \mathrm{C}$ in darkness and after soaking the leaves, turgid weight (TW) was measured with the help of balance. Dry weight (DW) was measured after oven drying the leaf samples at $72^{\circ} \mathrm{C}$ for 48 hours. Relative water content was described by the equation given by the Teulat et al. (2003).

$$
\text { RWC }(\%)=\text { FW-DW/TW-DW } \times 100
$$

Relative dry weight can be calculated by using the formula used by Ali et al. (2009).

$$
\mathrm{RDW}=\mathrm{DW} /(\mathrm{TW}-\mathrm{DW})
$$

\section{Assessment of Growth and Yield Parameters}

The randomly plants were collected from the pot for comparison of growth and yield parameters (from every line and treatment) and data were collected for plant height $(\mathrm{cm})$, number of tillers per plant, number of spikelet's per spike, number of grains per spike, spike weight (g) and grain yield per plant. To measuring head weight $(\mathrm{g})$, detached plants were placed in the sunlight for 5 days and their heads were weighed by using electric balance. The samples were thrashed for counting the number of grains per spike and grain yield per plant $(\mathrm{g})$.

\section{Statistical Analysis}

The data were analyzed using statistical software (Statistix 8.1) under factorial design with three replications following Steel et al, (1997). The mean values of the data were tested with least significance difference (LSD) test at the probability level of $5 \%$ $(\mathrm{P} \leq 0.05)$.

\section{Results}

\section{Analysis of Variance for Different Traits}

Analysis of variance indicated that the wheat lines used in this study were significantly different from each other for various morph-physiological attributes like flag leaf area (FLA), chlorophyll contents (CC), relative membrane permeability (RMP), relative water content (RWC) and excised leaf weight loss (ELWL) (Table 1). Likewise, various treatments used as crop growth promoting strategies significantly affected the FLA, CC, RMP, RWC and ELWL of wheat line (Table 1). Similarly, analysis of variance indicates that plant height $(\mathrm{PH})$, number of spikelet's per spike (SPS), number of grains per spike (GPS), spike weight (SW) and grain yield per plant (GYPP) were significantly different among the various wheat lines; results being non-significant for number of tillers per plant TPP (Table 2). Likewise, various crop growth promoting strategies significantly affected the PH, TPP, SPS, GPS, SW and GYPP of wheat lines (Table 2). The interaction of wheat genotypes with crop growth promoting strategies was non-significant for PH, TPP, SPS, SW and GYPP but significant for GPS (Table 2). The interaction between wheat lines with crop growth promoting strategies was non-significant for FLA and RWC but significant for CC, RMP and ELWL), Table 1.

Performance of Morph-Physiological Attributes in Response to Endophytes

Graphical expression of mean values of various wheat lines under different environments like Bacillus sp. MN54, Trichoderma sp. MN6 and their consortium application revealed that increased moisture characters significantly were elucidated in consortium application for FLA and CC, while highest RMP was recorded by the control and Bacillus sp. MN54, RWC significantly increased by the treatment of Trichoderma sp.MN6 and maximum ELWL was recorded in the control, Figure 1.

An increase of 28.6, 19.0 and $11.7 \%$ was measured in FLA by the application of consortium, bacteria and fungus respectively. It is seen that there was-18.9, -14.1 and $-4.9 \%$ decrease in the SFLA by the application of consortium, bacteria and fungus. There was 4.3, 2.9\% increase in the $\mathrm{CC}$ by the application of consortium and bacteria respectively but there will be decrease $-1.3 \%$ in $\mathrm{CC}$ by the application of fungus. There was $-6.3,0.0$ and $12.5 \%$ decrease in the RMP by the application of consortium, bacteria and fungus respectively. There was, $3.7,-2.6$ decreases in the RWC by the application of consortium and bacteria and $1.6 \%$ increase in the RWC by the application of fungus. There was 29, 22.6 and $12.9 \%$ increase in the RDW and 28.6, 14.3 and $0.0 \%$ increase in the SFLW by the application of consortium, bacteria and fungus. There was, $17.4 \%$ increase in the ELWL by the application of consortium and -42.1 and $27.4 \%$ decrease in the ELWL due to the application of bacteria and fungus respectively (Figure $3 \mathrm{~B}$ ).

Performance of Growth and Yield Parameters in Response to Endophytes

Graphical expression of mean values of various wheat lines under different environments like Bacillus sp. MN54, Trichoderma sp. MN6 and their consortium application revealed that increased growth and yield characters significantly were elucidated in consortium application for PH, SPS, GPS, SW and GYPP while for TPP, maximum values were seen in the application of Trichoderma sp. MN6, Figure 2.

Table 1 Mean squares from analysis of variance by using statistical software (Statistix 8.1) for morph-physiological characters of wheat

\begin{tabular}{l|ccccc}
\hline \multicolumn{1}{c|}{ SOV } & FLA & CC & RMP & RWC & ELWL \\
\hline $\mathrm{L}$ & $167.81^{*}$ & $33.86^{*}$ & $0.057^{*}$ & $294.01^{*}$ & $91.97^{*}$ \\
$\mathrm{~T}$ & $378.11^{*}$ & $128.93^{*}$ & $0.093^{*}$ & $136.18^{*}$ & $1146.94^{*}$ \\
$\mathrm{~L} \times \mathrm{T}$ & $0.98^{\mathrm{NS}}$ & $33.65^{\mathrm{NS}}$ & $0.032^{*}$ & $18.32^{\mathrm{NS}}$ & $75.23^{*}$ \\
Error & 4.28 & 3.26 & 0.008 & 19.86 & 18.92 \\
\hline
\end{tabular}

SOV $=$ Source of Variation; $\mathrm{L}=$ Lines; $\mathrm{T}=$ Treatment; $\mathrm{L} \times \mathrm{T}=$ Lines $\times$ Treatment, NS= non- significant and $*=$ significant at $5 \%$ probability, FLA $=$ Flag Leaf Area, $\mathrm{CC}=$ Chlorophyll Contents, RMP $=$ Relative Membrane Permeability, RWC $=$ Relative Water Contents, ELWL= Excised Leaf Weight Loss 
Table 2 Mean square from ANOVA by using (Stastix 8.1) for grain and yield attributes of wheat

\begin{tabular}{l|cccccc}
\hline \multicolumn{1}{c|}{ SOV } & PH & TPP & SPS & GPS & SW & GYPP \\
\hline L & $920.16^{*}$ & $3.18^{\mathrm{NS}}$ & $18.26^{*}$ & $254.07^{*}$ & $2.07^{*}$ & $30.22^{*}$ \\
$\mathrm{~T}$ & $868.63^{*}$ & $10.83^{*}$ & $188.18^{*}$ & $734.66^{*}$ & $9.57^{*}$ & $186.41^{*}$ \\
$\mathrm{~L} \times \mathrm{T}$ & $3.820^{\mathrm{NS}}$ & $1.81^{\mathrm{NS}}$ & $2.78^{\mathrm{NS}}$ & $14.57^{*}$ & $0.01^{\mathrm{NS}}$ & $1.79^{\mathrm{NS}}$ \\
Error & 14.91 & 1.96 & 2.90 & 7.69 & 0.056 & 2.07 \\
\hline
\end{tabular}

$\mathrm{SOV}=$ Source of Variation; $\mathrm{L}=\mathrm{Line}=\mathrm{T}=$ Treatment $\mathrm{L} \times \mathrm{T}=$ Line $\times$ Treatment, $\mathrm{NS}=$ non - significant and $*=$ significant at $5 \%$ probability, $\mathrm{PH}=\mathrm{Plant}$ Height, TPP= number of tillers per Plant, SPS= number of Spikelet's Per Spike, GPS= number of grains per Spike, SW= Spike Weight and GYPP= Grain Yield per Plant
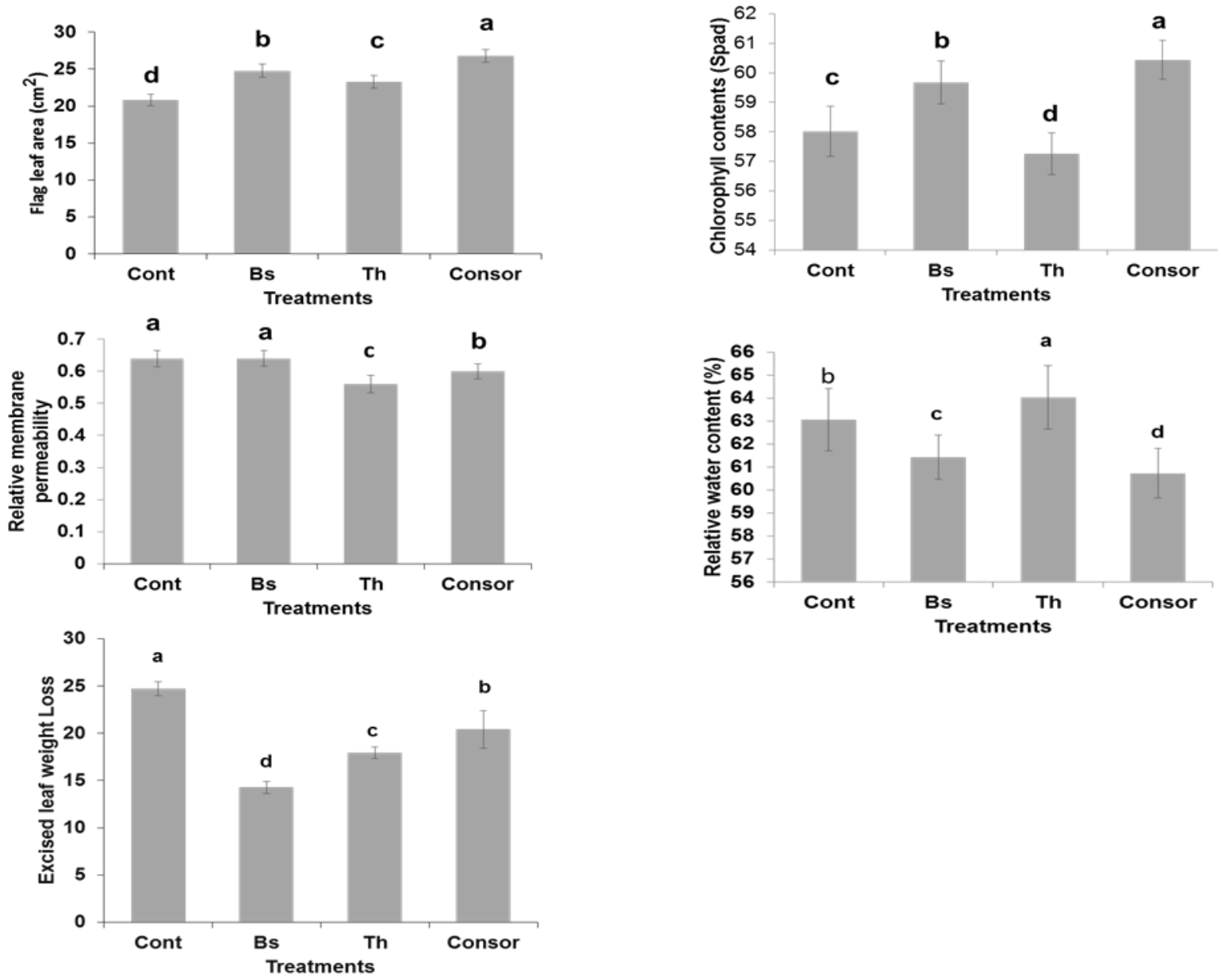

Figure 1 The statistical software (Statistix 8.1) was used for the mean comparison of three replicates by using factorial design for the morph- physiological characteristics of wheat.

Whereas Cont=control, Bs=Bacillus sp. MN54., Th=Trichoderma sp. MN6 and Consor=consortium (Bacillus sp. MN54 and Trichoderma sp. MN6). The means in the figures with same lettering are not statistically significant from each other according to the least significant difference (LSD) test at $\mathrm{P}=0.05$.

There was $37.1,31.4$ and $25.7 \%$ increase in the PH by the endophytic application of consortium, bacteria and fungus. It is observed that $23.7,14.6,7.7 \%$ increase in the PL by the application of consortium, bacteria and fungus. There was 56.031 .9 and $14.0 \%$ increase in the IL by the application of consortium, bacteria and fungus. By the application of endophytes there was $41.1,25.9,12.2 \%$ increase in the SL. There was 8.2, 4.1 and $2.0 \%$ increase in the PH and PL by the consortium, bacteria and fungus respectively. Likewise, there was $32.2,15.7$ and $13.4 \%$ increase in the SPS and 25.8, 16.4 and $6.1 \%$ increase in the GPS by the application of consortium, bacteria and fungus respectively. There was 52.8, 26.7 and 13.1\% increase in the SW by the application of consortium, bacteria and fungus. Similarly, increase of 30.8, 20.3 and $12.9 \%$ was observed in GYPP due to application of consortium, bacteria and fungus respectively but in the case of TPP 12.5, 9.4 and $14.1 \%$ increase by the application of consortium, bacteria and fungus respectively, Figure $3 \mathrm{~A}$.

\section{Performance of Various Wheat Advanced Lines Under} Different Inoculation Regimes

Among the lines, Maximum FLA recorded in the line $120\left(38.06 \mathrm{~cm}^{2}\right)$ and minimum FLA was found in the line $104\left(17.62 \mathrm{~cm}^{2}\right)$. Similarly maximum $\mathrm{CC}$ was found in the line 107 (20.04), while minimum CC was in the line 101 (8.05). The RMP was maximum in the line 101 (50) and minimum in the line $144(-41.18)$. Likewise highest RWC was recorded in the line 140 (5.21) and minimum in the line $123(-14.04)$. The highest ELWL was recorded in the $104(-53.71)$ and minimum ELWL was noted in the 
line 127 (135). Among the wheat lines highest PH was recorded in lines $113(24.03 \mathrm{~cm})$ and minimum in line 130 (9.64). The highest TPP was recorded in the line 130 (53.40) and minimum TPP was noted in the line 106 (14.29). Similarly maximum SPS recorded in the line 107 (53.05) but minimum SPS was recorded in the line 123 (8.74). The maximum GPS was observed in the line 127 (43.98) and minimum GPS was noted in the line 124 (6.04). The highest SW was recorded in the line 140 (90.09) while minimum in the line 128 (34.68). However, the maximum GYPP was recorded in the line 150 (51.63) and Minimum GYPP was recorded in the line 104 (13.11). (Table 3).
Effect of Consortium Application on Correlation Matrices for Different Morph-Physiological and Yield Attributes

FLA depicted significantly positive association with ELWL at the control level. CC had significant correlation with PH at the control level. SPS was noted that it had significantly positive correlation with RWC and GPS at consortium and control level respectively. GPS showed positive significant correlation with the SPS and SW at consortium and control level respectively. SW showed variables at consortium level as it had significantly positive interrelation with SPS and GPS at consortium level. GYPP reported that it had solid positive correlation with the TPP at consortium level (Table 4).

Table 3 Performance of various wheat advanced lines under different inoculation regimes

\begin{tabular}{llllllllllll}
\hline Lines & FLA & CC & RMP & RWC & ELWL & PH & TPP & SPS & GPS & SW & GYPP \\
\hline V-106 & 19.74 & -8.00 & 6.06 & -0.91 & -37.00 & 20.66 & -14.29 & 12.85 & 4.81 & 58.82 & 15.06 \\
V-142 & 26.17 & 12.82 & -6.02 & -4.56 & -36.32 & 11.74 & 34.56 & 50.04 & 37.32 & 43.46 & 33.65 \\
V-113 & 35.55 & -0.21 & 24.64 & 1.00 & 40.03 & 24.03 & 22.17 & 33.36 & 17.54 & 53.37 & 47.66 \\
V-140 & 32.89 & -2.72 & -17.65 & 5.21 & -17.42 & 9.92 & 12.60 & 23.79 & 12.10 & 90.09 & 32.20 \\
V-104 & 17.62 & 2.18 & -25.00 & -5.91 & -47.39 & 15.58 & 26.98 & 38.99 & 32.01 & 38.99 & 13.11 \\
V-124 & 24.04 & 6.75 & 29.09 & -12.76 & -40.68 & 18.58 & 29.40 & 35.92 & -6.06 & 50.54 & 43.20 \\
V-110 & 31.63 & 12.09 & 19.15 & 3.66 & 0.64 & 15.46 & 0.00 & 17.80 & 29.01 & 47.03 & 17.10 \\
V-137 & 25.11 & 3.12 & 24.44 & 3.04 & -32.72 & 22.90 & 32.08 & 42.45 & 15.29 & 75.94 & 23.56 \\
V-118 & 32.56 & -3.09 & 25.00 & -1.35 & -27.93 & 17.15 & -10.45 & 52.51 & 27.78 & 40.54 & 28.43 \\
V-101 & 31.77 & -8.05 & 50.00 & 0.84 & -53.71 & 13.73 & 21.75 & 21.95 & 32.97 & 91.84 & 28.00 \\
V-120 & 38.06 & 1.69 & -26.03 & -11.76 & -32.74 & 13.07 & 9.40 & 19.46 & 25.03 & 77.97 & 31.73 \\
V-130 & 19.61 & 17.33 & 0.00 & -12.89 & -28.20 & 9.64 & 53.40 & 23.36 & 28.84 & 45.96 & 51.63 \\
V-127 & 37.65 & -0.94 & -5.17 & 9.00 & 135.00 & 15.31 & 50.94 & 24.36 & 43.98 & 45.19 & 35.68 \\
V-107 & 34.18 & 20.04 & -11.76 & -6.01 & 52.20 & 14.14 & 5.87 & 53.05 & 35.81 & 58.16 & 31.94 \\
V-123 & 33.82 & -1.41 & -15.38 & -14.04 & -14.88 & 17.02 & -0.45 & 8.74 & 34.33 & 45.15 & 24.83 \\
V-144 & 31.64 & 16.55 & -41.18 & 2.71 & -4.29 & 15.98 & 17.02 & 35.03 & 19.61 & 80.26 & 37.07 \\
V-128 & 28.71 & 16.49 & -22.86 & -6.13 & -23.08 & 13.14 & 9.40 & 40.00 & 24.98 & 34.68 & 27.60 \\
V-135 & 27.96 & 1.03 & -5.26 & -8.94 & -42.00 & 19.39 & -9.57 & 42.07 & 32.23 & 38.39 & 29.02 \\
V-121 & 24.80 & -7.59 & -24.29 & -7.61 & -41.03 & 12.43 & -5.52 & 48.69 & 42.07 & 43.68 & 25.77 \\
V-126 & 29.56 & -0.77 & -30.14 & 0.28 & -43.90 & 23.14 & -5.52 & 35.92 & 26.25 & 80.62 & 42.39 \\
\hline
\end{tabular}

Note: The data is given in percentage increase/decrease of consortium application over control.

Table 4 Simple correlation matrices between different morph-physiological and yield attributes

\begin{tabular}{l|lllllllllll}
\hline & FLA & CC & RMP & RWC & ELWL & PH & TPP & SPS & GPS & SW & GYPP \\
\hline FLA & & 0.02 & -0.05 & 0.13 & 0.64 & 0.17 & 0.22 & 0.07 & -0.14 & -0.22 & 0.16 \\
CC & 0.12 & & -0.37 & -0.14 & 0.03 & 0.51 & 0.19 & 0.05 & 0.13 & 0.08 & 0.18 \\
RMP & -0.17 & -0.02 & & 0.27 & 0.04 & 0.09 & -0.06 & -0.05 & -0.16 & -0.14 & -0.05 \\
RWC & 0.02 & 0.23 & -0.19 & & -0.05 & -0.15 & 0.11 & 0.08 & -0.10 & -0.12 & -0.02 \\
ELWL & -0.39 & 0.08 & -0.07 & 0.23 & & -0.14 & 0.32 & -0.09 & -0.08 & -0.13 & 0.11 \\
PH & 0.24 & 0.17 & -0.22 & 0.13 & 0.44 & & 0.09 & 0.37 & 0.39 & 0.00 & 0.19 \\
TPP & 0.15 & 0.21 & 0.25 & -0.33 & 0.14 & 0.09 & & 0.14 & 0.14 & 0.08 & 0.32 \\
SPS & 0.01 & 0.26 & 0.21 & 0.49 & -0.07 & 0.35 & 0.02 & & 0.77 & 0.32 & 0.26 \\
GPS & 0.06 & 0.00 & -0.30 & -0.24 & 0.19 & 0.34 & -0.05 & 0.71 & & 0.54 & 0.11 \\
SW & 0.42 & 0.17 & -0.08 & -0.29 & 0.11 & 0.09 & 0.19 & 0.45 & 0.45 & & 0.01 \\
GYPP & 0.04 & 0.09 & 0.18 & 0.08 & 0.23 & 0.04 & 0.45 & 0.00 & 0.23 & 0.12 & \\
\hline
\end{tabular}

Where, un-shaded upper parenthesis shows correlation coefficients for control and lower shaded area demonstrates correlation matrices from varieties/lines treated with consortium of bacteria and fungi.

\section{Discussion}

Endophytes live inside the plants without causing any deleterious effect on their health, but some endophytes provide directly or indirectly benefits to their host plant (Hardoim et al., 2008; Shoresh et al., 2010). These endophytes either as single strain or multi-strain inoculum have previously exhibited mutualistic behavior when added to other plant species including grasses, corn, rice,
Douglas-fir and a variety of crop plants (Xin et al., 2009; Knoth et al., 2013; Knoth et al., 2014; Khan et al., 2012; Khan et al., 2015; DaSilveria et al., 2016). Combined application of endophytes can result in larger effects than those possible with individual inoculations (Knoth et al., 2013; Knoth et al., 2014; Rogers et al., 2012). 

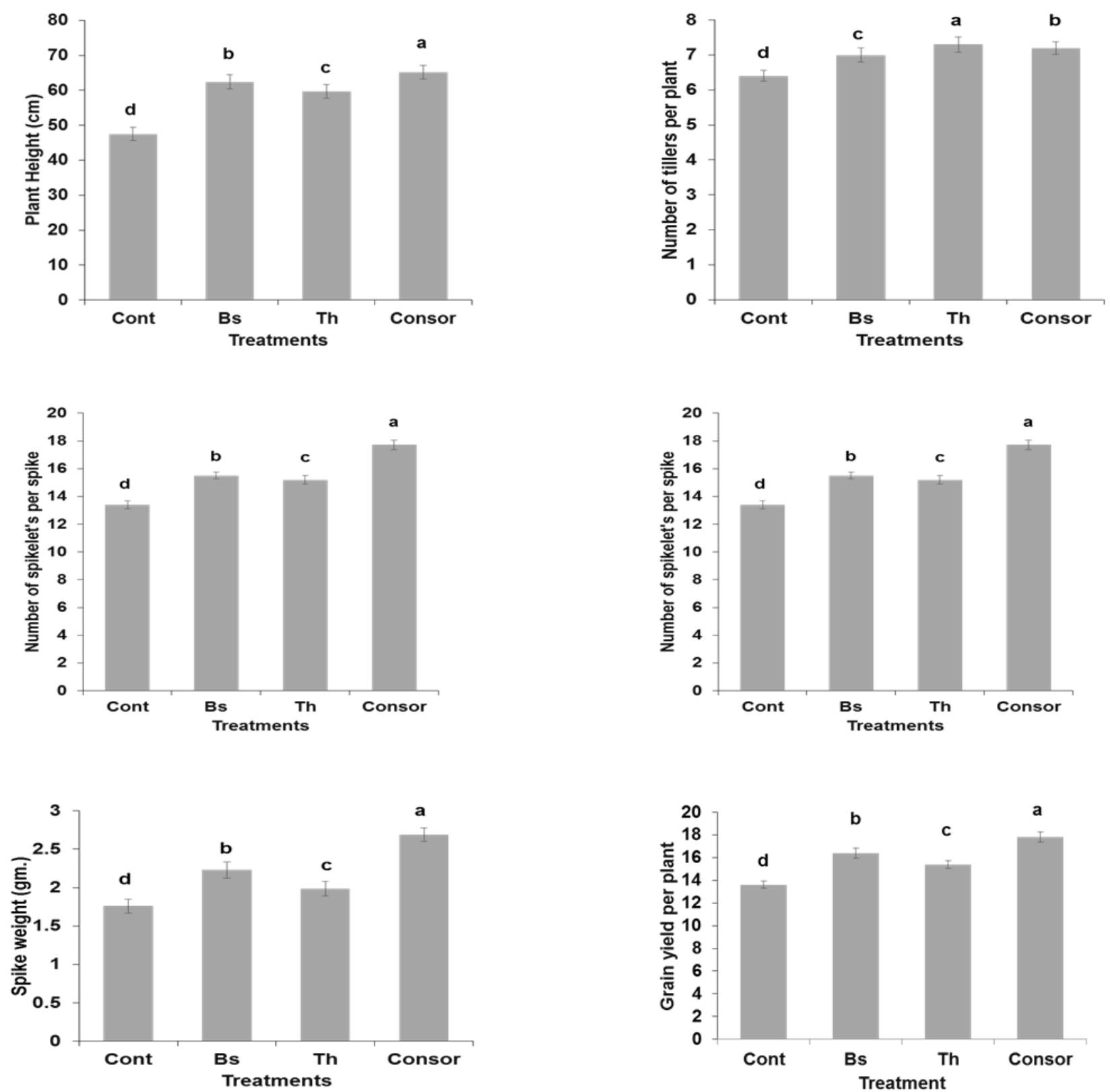

Figure 2 The statistical software (Statistix 8.1) was used for the mean comparison of three replicates by using factorial design for the growth and yield parameters of wheat.

Whereas Cont=control, Bs=Bacillus sp. MN54, Th=Trichoderma $\mathrm{sp}$. MN6 and Consor=consortium (Bacillus sp. MN54 and Trichoderma MN6). The means in the figures with same lettering are not statistically significant from each other according to the least significant difference (LSD) test at P= 0.05
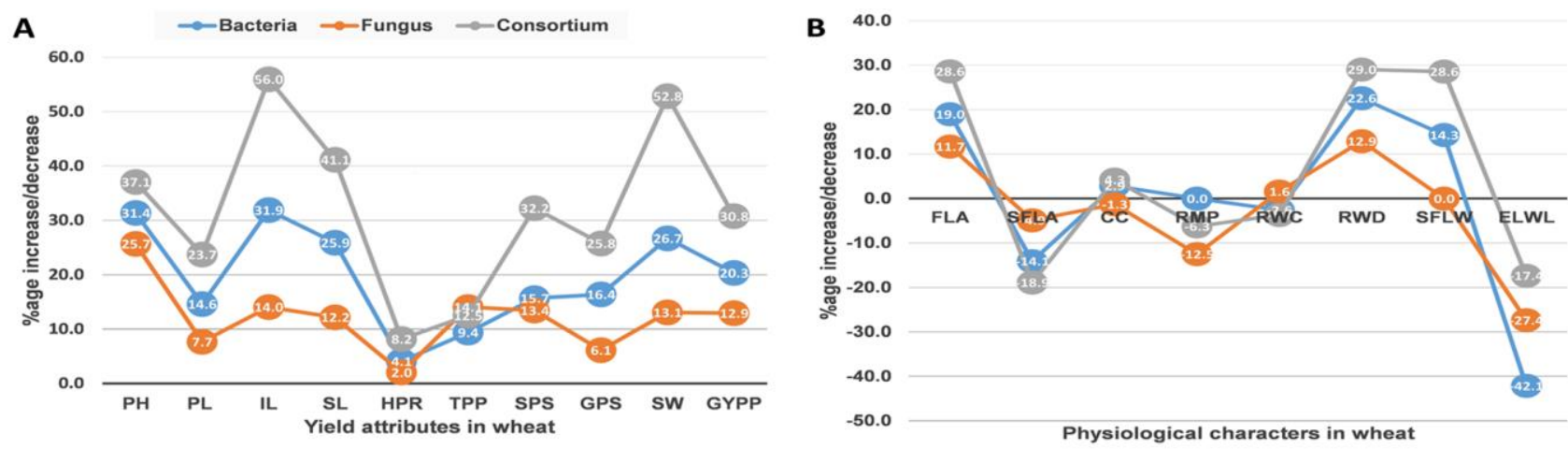

Figure 3 Percentage increase/decrease over control of morph-physiological attributes.

A) $\mathrm{PH}=$ Plant Height, $\mathrm{PL}=$ Peduncle Length, IL= Internode Length, $\mathrm{SL}=$ Spike Length, HPR= Plant height/ peduncle length Ratio, TPP= number of tillers per Plant, SPS= number of Spikelet's Per Spike, GPS= number of grains per Spike, $\mathrm{SW}=$ Spike Weight and GYPP= Grain Yield per Plant. B) FLA= Flag Leaf Area, SFLA= Specific Flag Leaf Area, CC= Chlorophyll Contents, RMP= Relative Membrane Permeability, RWC= Relative Water Contents, RDW= Relative Dry Weight, SFLW= Specific Flag Leaf Weight, ELWL= Excised Leaf Weight Loss 
In this study, the bacterial and fungal strains of different endophytes (Bacillus sp. MN54 and Trichoderma sp. MN6 were applied alone and in combination to evaluate their effects on various morphphysiological, growth and yield parameters of 20 different wheat lines in pot experiment. The statistically significant results were recorded by the application of consortium which resulted in improved physiology, growth and yield attributes of different wheat lines but in some cases only fungus or bacterial strain showed the best results.

The morpho-physiological traits such as flag leaf area, chlorophyll contents, relative membrane permeability, relative water content and excised leaf weight loss were assessed in response to various endophytes treatments. All of these traits showed improvement followed by the application of these endophytes in consortium. The increase in flag leaf area is possible due to the positive effects of endophytes on photosynthesis through production/stimulation of specific phytohormone(s) associated with leaf development (Zulini et al., 2007). This increase in leaf area would positively affect the productivity of wheat as FLA has been reported to be positively associated with grain yield (Ali et al., 2010). Other physiological aspects that might also be influencing the system are water-use efficiency related to photosynthesis, xylem hydraulic conductivity, and partitioning of photo assimilates. The delay of the decreasing photosynthetic activities by the inoculated endophytes corresponded with the delay of degradation of chlorophyll in the present study. Chlorophyll concentration is positively connected to photosynthetic activities of PSII, especially under water stressed conditions (Caudle et al., 2014). Similarly, the inoculated endophyte consortia may help the host plants to reserve chlorophyll molecules in the leaves by providing fixed nitrogen and phytohormones which eventually increase the host plants' adaptation to the stressed environment (Lawlor et al., 2009).

The grain yield and its attributes were also evaluated in response to various applications of endophytes. We were able to demonstrate that application of endophytic bacteria and fungus in combination resulted in 32.2, 25.8 and $30.8 \%$ increase in number of spikelet's, grains per spike and grain yield per plant respectively. Buensanteai et al. (2014) reported that the interaction between Glomus mosseae and Trichoderma harzianum give significant increase in growth parameters of chilli plants such as shoot and root lengths, dry weight of shoot and root, number of leaves, number of branching. These are due to the ability of Trichoderma sp. to production of phytohormones such as auxin and gibberellin which enhance plant growth (Abood et al., 2008), increase nutrient uptake (Al- Kurtany et al., 2008) and mobilization of inorganic nutrients (Kaya et al., 2009; Lopez -Bucio et al., 2005). Bacillus sp. can also help plants for fixing atmospheric nitrogen and production of siderophores which can solubilize and sequester iron in the plants (Mayak et al., 2004). They produce many growth stimulating agents like Indole acetic acid (IAA), Gibbrelic acid (GA) and Abscisic acid (ABA) and cytokinin which play a very important role in the plant growth and defense mechanism (Mayak et al., 2004; Perring et al., 2007; Arendt et al., 2013). Moreover, the application of these endophytes increased concentrations (up to $5 \%$ ) caused significant increase in grain yield per plant. The increase in yield of wheat was found similar to some previous findings (Nashwa et al., 2008; Sharma et al., 2012), where the formulation of Trichoderma sp. treatments enhanced green yield of bean plants compared to infected control. In this experiment the increase in yield can also be attributed to the application of Trichoderma harzianum (Th3) bio-formulation along with the Farm yard manure which helped increasing the colonies by providing nutrient to Trichoderma thereby increasing the plant growth and yield of wheat. Generally, fungi have been reported to possess greater ability to solubilize phosphate than bacteria, viz., $B$. subtilis and $B$. megatarium (Rajankar et al., 2007), this may explain the greater effectiveness of $T$. harzianum than B. subtilis in growth promotion and crop production. Thus, the use of these specific bio-agents in agriculture also helped in sustenance and growth promotion of plants.

\section{Conclusions}

In conclusion, we resulted that a consortia of endophytic bacteria and fungi significantly enhanced plant growth, yield and tolerance of water deficit stress of different wheat lines under pots. To produce stable high yield of wheat under stresses imposed by climate change, a plant-microbe interaction could be a key to adapting plants to a water limited environment. So, consortia of endophytic microbes can greatly promote the progress of plants into the fundamental mechanisms of symbiosis and increased the yield in an environmentally sustainable way.

\section{Acknowledgement}

The authors would like to thank Higher Education Commission of Pakistan for partially supporting this study through project number HEC/IPFP/SRG2014-828. We also thank Dr. Muhammad Farooq from the Department of Agronomy, UAF for critics and improvement of the article.

\section{References}

Abood HM, Saeed FH, Abood MR. 2008. Derection of gibberellins and auxins like compounds and the phyrohormoethylene in culture filterate of three isolates of Trichoderma harzianum. The Iraq J. agricul. Sci., 39 (2), 12-18.

Aboud MA, Mosaye A, Abid RM. 2014. Interaction of Bacillus subtilis and Trichoderma harzianum on growth and yield of cucumber (Cucumis sativus L.). Int. J. Curr. Res., 6 (8), 77547758.

Adams P, De-Leij MFAA, Lynch JM. 2007. Trichoderma harzianum Rifai 1295-22 mediates growth promotion of crack willow (Salix fragilis) saplings in both clean and metalcontaminated soil. Microbial. Ecol., 54 (2), 306-313.

Ahmad S, Ali H, Ur Rehman A, Khan RJZ, Ahmad W, Fatima Z, Abbas G, Irfan M, Ali H, Khan MA, Hasanuzzaman M. 2015. Measuring Leaf Area of Winter Cereals by Different Techniques: A Comparison. Life, 13 (2), 117-125.

Al- kurtany AKE, AL- Zubaide NA, Al- Thehaby RM. 2008. The effect of inoculation by Penicillium, Trichoderma, Aspergillus fungi and their interaction with Mycorrhiza fungus Glomus on growth of Eggplant and its yield. Tikret Univ. J. Agric. Sci., 8(1), 254-261. 
Ali MA, Hussain M, Khan MI, Ali Z, Zulkiffal M, Anwar J, Sabir W, Zeeshan M. 2010. Source-sink relationship between photosynthetic organs and grain yield attributes during grain filling stage in spring wheat (Triticum aestivum L.). Int. J. Agric. Biol., 12 (4), 509-515.

Ali MA, Niaz S, Abbas A, Sabir, W, Jabran K. 2009. Genetic diversity and assessment of drought tolerant sorghum landraces based on morph-physiological traits at different growth stages. Plant Omics. 2 (5), 214-227.

Arendt KR, Baltrus DA, Arnold AE. 2013. Diversity and specificity of phenotypic effects of endohyphal bacteria on foliar fungal endophytes. Phytopathology,103(6),8.

Azarmi R, Hajieghrari B, Giglou A. 2011. Effect of Trichoderma isolates on tomato seedling growth response and nutrient uptake. Afr. J. Biotechnol., 10 (31), 5850-5855.

Bacon CW, White J, 2000. Microbial endophytes. CRC Press. Taylor \& Francis Group, New York, USA.

Bais HP, Fall R, Vivanco JM. 2004. Biocontrol of Bacillus subtilis against infection of Arabidopsis roots by Pseudomonas syringae is facilitated by biofilm formation and surfactin production. Plant Physiol., 134 (1), 307-319.

Barutcular C, Toptas I, Turkten H, Yildirim M, Mujde KOC. 2015. SPAD greenness to estimate genotypic variation in flag leaf chlorophyll in spring wheat under Mediterranean conditions. Turk. J. Field Crops, 20 (1), 1-8.

Buensanteai N, Sompong M, Saengchan C, Thumanu K. 2014. The cellular components of cucumber seedlings after primed with plant growth promoting rhizobacteria, Bacillus subtilis Bs008. Afr. J. Microbiol. Res., 8(10), 1006-1011.

Caudle KL, Johnson LC, Baer SG, Maricle BR. 2014. A comparison of seasonal foliar chlorophyll change among ecotypes and cultivars of Andropogon gerardii (Poaceae) by using nondestructive and destructive methods. Photosynthetica, 52 (4), 511-518.

DaSilveira APD, Sala VMR, Cardoso EJBN, Labanca EG, Cipriano M.A.P. 2016. Nitrogen metabolism and growth of wheat plant under diazotrophic endophytic bacteria inoculation. App. Soil Ecol., 107, 313-319.

Din GMU, Ali MA, Abbas A, Naveed N, Anwar J, Tanveer MH. 2017. Effect of leaf rust disease on various morphophysiological and yield attributes in bread wheat. Pak. J. Phytopathol., 29 (1), 117-128.

Erturk Y, Ercisli S, Haznedar A, Cakmakci R. 2010. Effects of plant growth promoting rhizobacteria (PGPR) on rooting and root growth of kiwifruit (Actinidia deliciosa) stem cuttings. Biol. Res., 43 (1), 91-98.

FAOSTAT. 2012. FAOSTAT. Food and Agriculture Organization of the United Nations Rome, Italy.

Firáková S, Šturdíková M Múčková M. 2007. Bioactive secondary metabolites produced by microorganisms associated with plants. Biol., 62 (3), 251-257.

Grichko VP. Glick BR. 2001. Amelioration of flooding stress by ACC deaminase-containing plant growth-promoting bacteria. Plant Physiol. Biochem., 39 (1), 11-17.

Han HS, Lee KD 2005. Physiological responses of soybeaninoculation of Bradyrhizobium japonicum with PGPR in saline soil conditions. Res. J. Agric. Biol. Sci., 1 (3), 216-221.

Hardoim PR, Overbeek V, Leo S, Elsas DJV. 2008. Properties of bacterial endo-phytes and their proposed role in plant growth. Trends Microbiol., 16 (10) 463-471.

Harman GE, Howell CR, Vitrebo A, Chet I, Lorito M. 2004. Trichoderma species opportunistic, arivulent plant symbionts. Nat. Reviw. Microbiol. 2, 43-56.

Idris EE, Bochow H, Ross H, Borriss R. 2004. Use of Bacillus subtilis as biocontrol agent. VI. Phytohormonelike action of culture filtrates prepared from plant growth-promoting Bacillus amyloliquefaciens FZB24, FZB42, FZB45 and Bacillus subtilis FZB37. Zeitschrift für Pflanzenkrankheiten und Pflanzenschutz/J Plant Dis. Prot., 111:583-597.

Joseph, B, Patra RR, Lawrence, R. 2007. Characterization of plant growth promoting rhizobacteria associated with chickpea (Cicer arietinum L.). Int. J. Plant Prod., 1 (2), 141-152.
Kaya C, Ashraf M, Sonmez O, Aydemir S, Tuna AL, Cullu MA. 2009. The influence of arbuscular mycorrhizal colonisation on key growth parameters and fruit yield of pepper plants grown at high salinity. Sci. Hortic., 121 (1), 1-6.

Khan Z, Guelich G, Phan H, Redman R, Doty S. 2012. Bacterial and yeast endophytes from poplar and willow promote growth in crop plants and grasses. ISRN Agron 2012: Article ID 890280.

Khan Z, Kandel SL, Ramos DN, Ettl GJ, Kim SH, Doty SL. 2015. Increased biomass of nursery-grown Douglas-fir seedlings upon inoculation with diazotrophic endophytic consortia. Forests, 6 (1), 3582-3593.

Knoth JL, Kim SH, Ettl GJ, Doty SL. 2013. Effects of cross host species inoculation of nitrogen-fixing endophytes on growth and leaf physiology of maize. GCB Bioenergy, 5 (4), 408-418.

Knoth JL, Kim SH, Ettl GJ, Doty SL. 2014. Biological nitrogen fixation and biomass accumulation within poplar clones as a result of inoculations with diazotrophic endophyte consortia. New Phytol., 201 (2), 599-609.

Lawlor DW, Tezara W. 2009. Causes of decreased photosynthetic rate and metabolic capacity in water-deficient leaf cells: a critical evaluation of mechanisms and integration of processes. An. Bot., 103, 561-579.

Lawlor DW. 2013. Genetic engineering to improve plant performance under drought: physiological evaluation of achievements, limitations, and possibilities. J. Exp. Bot., 64 (1), 83-108.

Lopez-Bucio J, Cruz-Ram'irez A, P'erez-Torres A, Ram'irezPimentel JG, 'anchez-Calder' on LS, Herrera-Estrella L. 2005. Root architecture. In: Plant Architecture and Its Manipulation, ed. C. Turnbull, pp. 181-206. Blackwell Scientific, Oxford, UK. Mastouri F, Björkman T, Harman GE. 2010. Seed treatment with Trichoderma harzianum alleviates biotic, abiotic, and physiological stresses in germinating seeds and seedlings. Phytopathology, 100 (11), 1213-1221.

Mayak S, Tirosh T, Glick BR. 2004. Plant growth-promoting bacteria that confer resistance to water stress in tomatoes and peppers. Plant Sci., 166 (2), 525-530.

Murali M, Amruthesh KN, Sudisha J, Niranjana SR, Shetty HS. 2012. Screening for plant growth promoting fungi and their ability for growth promotion and induction of resistance in pearl millet against downy mildew disease. J. Phytol., 4, 30-36.

Nashwa SMA, Abo-Elyousr KA, Hassan MA. 2008. Evaluation of Trichoderma species as biocontrol agent for damping-off and wilt diseases of Phaseolus vulgaris L. and efficacy of suggested formula. Egypt J. Phytopathol., 36, 81-93.

Pandey B, Bhattacharya C, Singh S. 2013. Effect of pesticides and insecticides on biofertilizer. Int. J. Adv. Biol. Res., 3 (4), 563566.

Perring D, Boiero ML, Masciarelli OA, Penna C, Ruiz OA, Cassán FD, Luna MV. 2007. Plant-growth-promoting compounds produced by two agronomically important strains of Azospirillum brasilense, and implications for inoculant formulation. Appl. Microbiol. Biotechnol., 75 (5), 1143-1150.

Rajankar PN, Tambekar, DH, Wate SR. 2007. Study of phosphate solubilisation efficiencies of fungiand bacteria isolated from saline belt of purna river basin. Res. J. of Agric. Biol. Sci., 3 (6), 701-703.

Rogers A, McDonald K, Muehlbauer M.F, Hoffman A, Koenig K, Newman L, Lelie D. 2012. Inoculation of hybrid poplar with the endophytic bacterium Enterobacter sp. 638 increases biomass but does not impact leaf level physiology. GCB Bioenergy, 4 (3), 364-370.

Sharma P, Patel AN, Saini MK, Deep S. 2012. Field demonstration of Trichoderma harzianum as a plant growth promoter in wheat (Triticum aestivum L). J. Agric. Sci., 4 (8), 65-73.

Shoresh M, Harman GE, Mastouri F. 2010. Induced systemic resistance and plant responses to fungal biocontrol agents. Annu. Rev. Phytopathol., 48, 21-43.

Steel RGD, Torrie JH, Deekey DA, 1997. Principles and Procedures of Statistics: A Biometrical Approach, 3rd edition. McGraw Hill Book Co., New York 
Teulat B, Zoumarou-Wallis N, Rotter B, Salem MB, Bahri H, This D. 2003. QTL for relative water content in field-grown barley and their stability across Mediterranean environments. Theor. Appl. Genet., 108 (1), 181-188.

Verhulst N, Govaerts B, Verachtert E, Castellanos-Navarrete A, Mezzalama M, Wall P, Deckers J Sayre KD. 2010. Conservation Agriculture, Improving Soil Quality for Sustainable Production Systems? In: Lal, R., Stewart, B.A. (Eds.), Advances in Soil Science: Food Security and Soil Quality. CRC Press, Boca Raton, FL, USA, pp. 137-208.

Waheed AQ, Hassan HR, Abbas BA, Nawar HH. 2014. Evolution of some growth promoting bacterial strains exist on Eggplant root Solanumm elongena L. against Rhizoctonia solani. J. Biotechnol. Res. Cent., 8 (1),14-19.

Xin G, Zhang G, Kang JW, Staley JT, Doty SL. 2009. A diazotrophic, indole-3-acetic acid-producing endophyte from wild cottonwood. Bio. Fertil. Soils, 45 (6), 669-674.
Yang A, Akhtar SS, Iqbal S, Amjad M, Naveed M, Zahir ZA, Jacobsen SE. 2016. Enhancing salt tolerance in quinoa by halotolerant bacterial inoculation. Funct. Plant. Biol., 43(7), 632-642.

Yang G, Rhodes D, Joly RJ. 1996. Effects of high temperature on membrane stability and chlorophyll fluorescence in glycinebetaine-deficient and glycinebetaine-containing maize lines. Funct. Plant Biol., 23 (4), 437-443.

Yedidia I, Shrivasta AK, Kapulnik Y, Chet I. 2001. Effect of Trichoderma harzianum on microelement concentration and increased growth of cucumber plants. Plant Soil, 235 (2), 235242.

Zulini L, Rubinigg M, Zorer R, Bertamini M. 2007. Effects of drought stress on chlorophyll fluorescence and photosynthetic pigments in grapevine leaves (Vitis Vinifera CV. 'white Riesling). Acta. Hortic., 754, 289-294. 